\title{
Effects of Kigelia africana Leaves on Survival, Reproduction and Growth of Earthworm (Eisenia fetida)
}

\author{
Gagopale Bosekeng* \\ Department of Agricultural Research, Horticulture Program, Ministry of Agricultural \\ Development and Food Security, Francistown, Botswana \\ *Corresponding author
}

\section{A B S T R A C T}

\begin{tabular}{|l|}
\hline Ke y w or d s \\
Sausage tree, \\
$\begin{array}{l}\text { Earthworm, } \\
\text { Cowdung, Leaves, } \\
\text { Growth }\end{array}$ \\
\hline Article Info \\
\hline $\begin{array}{l}\text { Accepted: } \\
\text { 20 December 2020 } \\
\text { Available Online: } \\
\text { 10 January 2021 }\end{array}$ \\
\hline
\end{tabular}

\begin{abstract}
Earthworms support the decomposition of biodegradable matters for the reduction of organic pollution. The survival, reproduction and growth of locally available earthworm (Eisenia fetida) was assessed in Kigelia africana leaves/sausage tree leaves (STL)or waste and cowdung at different ratios $\left(\mathrm{STL}_{0}, \mathrm{STL}_{25}, \mathrm{STL}_{50}, \mathrm{STL}_{75}\right.$ and $\left.\mathrm{STL}_{100}\right)$ in an experimental pots for 120 days. Pots were arranged in a complete randomized block design with four replications and the experiment was done twice in 2019. Number of adult worms, weight gained and number of hatchlings were recorded. The growth of earthworms showed significant differences in response to substrate treatments. Maximum number of worms was observed at 105 days. Weight of worms significantly decreased with the increase content of leaves.STL 50 produced significantly more hatchlings than other substrates content. Waste or leaves of $K$. africana tree can be considered as a substrates for the earthworms.
\end{abstract}

\section{Introduction}

Kigelia Africana (Lam.) Benth,is a native tree to Africa, widely distributed across Southern, Central and Western Africa. K. africana is commonly referred to as sausage tree due to the shape of its fruits. In Botswana, it is named Moporoto and is predominately found in the Northern and the Eastern part of the country. Fruits of $K$. Africana are grey-brown, often more than $30 \mathrm{~cm}$ in length and up to 18 $\mathrm{cm}$ in diameter (Arkhipov et al., 2014). The fruits have therapeutic properties and traditionally used for treating syphilis and ulcers (Dhungana et al., 2016). The extracts of the leaves of $K$. Africana contains antimicrobial, antioxidant and enhance healing of wounds (Agyare et al., 2013).

In Impala Research Station, Botswana, $K$. africana forms part of the landscape. This enormous tree during spring, relinquish abundant leaves which in return constitutes waste and these leaves do not decompose easily, making landfills in the station to fill up beyond their capacity so often, dictating for a new landfills. When the landfills are full and the new ones are not prepared, the leaves will be tossed to and from by winds. This pause a concern, as improperly handled leaves can 
have a devastating consequence on the surroundings. But, as the sites of landfills in the station are being established from time to time in order to address this situation, agricultural land is being reduced.

In combating scattered leaves and managing landfills capacities, burning of leaves remained a major practice. Consequently, burning leaves can be a tremendous health hazard as toxic pollutants are released in to the atmosphere (Sivertsen, 2006) and can result in respiratory diseases. Subsequently, burning generate greenhouse gases which contribute to climate change and this phenomenon is a global concern (Hoklis and Sharp, 2014). Thus, alternative friendly ways in combating $K$. Africana leaves rather than continuous surveying and digging of pits or burning the leaves ought to be sought, and vermicomposting is inevitable. Vermicomposting is an eco-biological process for waste management by using earthworms to convert waste into organic manure. Ndegwa et al., (2000), highlighted that vermicomposting is increasingly becoming popularas a waste management technique. According to Hussaini (2013), vermicomposting reduces wastes and consequently saves landfills space. Earthworms are known for degrading (feeding) on different plant materials and during the feeding process, they release casts which are useful friendly products such as vermicompost (Devi and Prakash, 2015), vermitea or vermiwash (Kibatu and Mamo, 2014). Thus, by introducing earthworms to $K$. africana leaves, environment will be relieved from scatted leaves and burning of the leaves will be avoided as worms will be feeding on them, spontaneously, yielding out organic fertilizer. However, the rate of degradation depends on the quality or palatability of material feeding the worms. Apart from manufacturing of useful products during the degradation of plants materials by earthworms, reproduction and growth of worms takes place, indicating the suitability of host material as a suitable substrate.

Therefore, this study was set to establish the survival, reproduction and growth of earthworm (Eisenia fetida (Savigny)) (Lumbricidae) on Kigelia africana leaves, as a substrate.

\section{Materials and Methods}

\section{Experimental site description}

A pot experiment was conducted in March 2019 and then repeated in April 2019at Impala Research Station which is adjacent to the city of Francistown, in North East, Botswana. The area is flat with an altitude of $1020 \mathrm{~m}$ above sea level. The area is occasioned by local climatic conditions of low rainfall and dry periods (between April and October) and wet season (between November and March), with an annual rainfall of about $630 \mathrm{~mm}$.

\section{Earthworms and substrates}

Earthworms, sausage tree leaves (STL)and cowdung (CD) used during this study were sourced from Impala Agricultural Research Station, Botswana. Cowdung was used as a control and making substrate ratio since it is a common earthworm substrate and is abundant in the station.

\section{Experimental design}

The leaves and cowdung were pre-composted for 21 days under the tree shade in order to catalyze composting and were turned over every 7 days to eliminate volatile toxic gases which might be detrimental to worms (Bhat et al., 2016).Experiment treatments consisted of; $\mathrm{STL}_{0}=0 \%$ (0 g STL + $\left.500 \mathrm{~g} \mathrm{CD}\right), \mathrm{STL}_{25}=$ $25 \%$ (125 g STL + 375 g CD), STL $_{50}=50 \%$ 
$(250 \mathrm{~g} \mathrm{STL}+250 \mathrm{~g} \mathrm{CD}), \mathrm{STL}_{75}=75 \%(375 \mathrm{~g}$ $\mathrm{STL}+125 \mathrm{~g} \mathrm{CD})$ and $\mathrm{STL}_{100}=100 \%(500 \mathrm{~g}$ STL + 0 g CD). Treatments were put in pots (containers)measuring a height of $20 \mathrm{~cm}$, $24 \mathrm{~cm}$ wide at the top and $7.9 \mathrm{~cm}$ wide at the base and were arranged as complete randomized block design and replicated four times. After filling containers with the treatment mixture, five adult worms (with clitellum) were inoculated in each container which were moistened with tap water and kept for the entire experiment (120 days). Containers were covered with blacknet shade $(80 \%)$ to keep worms under darkness.

Moisture content was maintained to $65-75 \%$ by sprinkling with tap water at an interval of 3 days. No supplementary feed of substrates for the entire duration of the experiment. Worms were manually separated from the substrates, counted and weighed, thereafter, returned to their respective containers. Hatchlings were also counted as soon as were identified. This was done every 15 days till the last day of the experiment.

\section{Statistical analysis}

Analysis of variance was done on all the measured parameters to determine significance differences between means of treatments using SAS program, and Tukey's test at $\mathrm{P}<0.05$.

\section{Results and Discussion}

Different substrates have been reported to affect the development and growth of worms (Sogbesan and Ugwumba, 2006; Suthar, 2007). In this study, different substrates mixtures of sausage tree leaves with cowdung resulted in survival, reproduction and growth of E. fetida. Number of initial worms (5)inoculated in the containers declined to 4.55 worms at $15^{\text {th }}$ day, thereafter, increased with an increase of days and the highest number of worms was recorded on $105^{\text {th }}$ day in both experiments (Table 1).

This indicates that worms were not accustomed to the substrates during the initial days of the experiment. An increase of worm populations during the ongoing $\left(60^{\text {th }}\right.$ day) of experiment was previously reported by Bhat et al., (2015) and they attributed that to the quality of substrate .During the first experiment, worms increased significantly $(\mathrm{P}<0.05)$ with a decrease of leaves content and maximum number (5.69) of worms was in $\mathrm{STL}_{0}$ though it was not significantly different from the number of those worms in $\mathrm{STL}_{25}, \mathrm{STL}_{50}$ and $\mathrm{STL}_{100}$. While in the second experiment, $\mathrm{STL}_{0}$ produced the least worms though they were not significantly different from the number of worms produced from $\mathrm{STL}_{100}$. The maximum number (4.66) of worms was recorded on $\mathrm{STL}_{75}$ but they were not significantly different from those of $\mathrm{STL}_{25}$ (4.63), STL 50 (4.50) and $\mathrm{STL}_{100}$ (4.41). A substrate containing $0 \%$ and $100 \%$ sausage tree leaves recorded statistically the same number of worms, thus either the cowdung or sausage tree leaves can be used to feed the worms. This results differs with the previous findings where cowdung was mixed with other tree leaves or organic materials. Bhat et al., (2016) recorded significantly high number $(59.0 \pm 2.64)$ of worms on cattle dung compared to $(21.16 \pm 2.33)$ on pressmud sludge. The growth and reproduction of $E$. fetida was evaluated using cow manure, dry leaves and sheep/goat manure as substrates by Siddique et al., (2005), and they reported a significantly higher growth rate in cow manure. Tripathi et al., (2015), studied five different types of feeding materials for $E$. fetida and they reported the highest multiplication of worms in cowdung feed.

Maximum weight (4.0 g) of worms in the first experiment was recorded at $105^{\text {th }}$ day though it was not significantly $(\mathrm{P}<0.05)$ different 
from the weight recorded on $15^{\text {th }}$ day, $45^{\text {th }}$ and $120^{\text {th }}$ day of experiment (Table 1). While in the second experiment, the maximum weight $(5.7 \mathrm{~g})$ of worms was noted on the $30^{\text {th }}$ day and was significantly different compared to those recorded on other days. During the entire duration of the experiment, there was no clear trend on weight of worms in the first experiment compared to the second one and no substantial explanation regarding that from this study. A fluctuating growth pattern of worms was previously reported (Karmegam and Daniel, 2009; Viljoen and Reinecke, 1989). Weight of worms significantly decreased with an increased content of the leaves in both experiments with $\mathrm{STL}_{0}$ producing the heaviest worms. This is in the same line with the findings of Sangwan et al., (2010) where cowdung was mixed with press mud as substrate for E. fetida. Siddique et al., (2005) also reported significant increase of worm weight in cowdung manure than in dry leaves.

Table.1 The survival, reproduction and growth of Eisenia fetida on Kigelia africana leaves

\begin{tabular}{|c|c|c|c|c|c|c|}
\hline \multirow[t]{2}{*}{ Duration (days) } & \multicolumn{3}{|c|}{ First Experiment } & \multicolumn{3}{|c|}{ Second Experiment } \\
\hline & $\begin{array}{l}\text { Number } \\
\text { of worms }\end{array}$ & $\begin{array}{l}\text { Mass of } \\
\text { worms (g) }\end{array}$ & $\begin{array}{l}\text { Number of } \\
\text { hatchlings }\end{array}$ & $\begin{array}{l}\text { Number } \\
\text { of worms }\end{array}$ & $\begin{array}{l}\text { Mass of } \\
\text { worms (g) }\end{array}$ & $\begin{array}{l}\text { Number of } \\
\text { hatchlings }\end{array}$ \\
\hline 15 & $4.55 \mathrm{bc}$ & $3.3 \mathrm{abc}$ & $\ldots \ldots$ & $4.25 \mathrm{c}$ & $3.1 \mathrm{~b}$ & $\ldots \ldots$ \\
\hline 30 & $4.60 \mathrm{bc}$ & 2.6 cde & $1.0 \mathrm{~d}$ & $4.35 \mathrm{bc}$ & $5.7 \mathrm{a}$ & $1.0 \mathrm{~d}$ \\
\hline 45 & $4.60 \mathrm{bc}$ & $3.7 \mathrm{ab}$ & $12.50 \mathrm{~cd}$ & $4.20 \mathrm{c}$ & $2.8 \mathrm{cb}$ & $2.0 \mathrm{~d}$ \\
\hline 60 & $4.00 \mathrm{c}$ & $3.0 \mathrm{bcd}$ & $32.20 \mathrm{bcd}$ & $4.10 \mathrm{c}$ & $2.6 \mathrm{cb}$ & $18.44 \mathrm{~cd}$ \\
\hline 75 & $4.60 \mathrm{bc}$ & $2.5 \mathrm{de}$ & $52.21 \mathrm{abc}$ & $4.10 \mathrm{c}$ & $2.8 \mathrm{cb}$ & $30.00 \mathrm{bcd}$ \\
\hline 90 & $5.55 \mathrm{ab}$ & $2.1 \mathrm{e}$ & $59.30 \mathrm{ab}$ & $4.20 \mathrm{c}$ & $3.1 \mathrm{~b}$ & $47.40 \mathrm{abc}$ \\
\hline 105 & $6.45 \mathrm{a}$ & $4.0 \mathrm{a}$ & $75.80 \mathrm{ab}$ & $5.37 \mathrm{a}$ & $2.3 \mathrm{c}$ & $65.50 \mathrm{ab}$ \\
\hline 120 & $6.00 \mathrm{a}$ & $3.4 \mathrm{ab}$ & $88.60 \mathrm{a}$ & $4.95 \mathrm{ab}$ & $2.3 \mathrm{c}$ & $90.10 \mathrm{a}$ \\
\hline \multicolumn{7}{|l|}{$\begin{array}{l}\text { Substrate } \\
\text { mixture }\end{array}$} \\
\hline $\mathrm{STL}_{0}$ & $5.69 \mathrm{a}$ & $4.1 \mathrm{a}$ & $14.75 \mathrm{c}$ & $3.93 \mathrm{~b}$ & $3.7 \mathrm{a}$ & $21.68 \mathrm{~b}$ \\
\hline STL $_{25}$ & $5.09 \mathrm{a}$ & $3.3 \mathrm{~b}$ & $53.13 \mathrm{~b}$ & $4.63 \mathrm{a}$ & $3.6 \mathrm{a}$ & $70.71 \mathrm{a}$ \\
\hline STL $_{50}$ & $5.44 \mathrm{a}$ & $2.9 \mathrm{~b}$ & $95.76 \mathrm{a}$ & $4.50 \mathrm{a}$ & $3.2 \mathrm{a}$ & $76.95 \mathrm{a}$ \\
\hline STL $_{75}$ & $4.16 b$ & $2.8 \mathrm{cb}$ & $71.92 \mathrm{~b}$ & $4.66 \mathrm{a}$ & $2.5 \mathrm{~b}$ & $57.36 \mathrm{a}$ \\
\hline $\mathrm{STL}_{100}$ & $4.83 \mathrm{ab}$ & $2.3 \mathrm{c}$ & $20.61 \mathrm{c}$ & $4.41 \mathrm{ab}$ & $2.6 \mathrm{~b}$ & $8.68 \mathrm{~b}$ \\
\hline
\end{tabular}

$\mathrm{STL}=$ Sausage tree leaves

Hatchlings were observed for the first time on the $30^{\text {th }}$ day in both experiments and the number of hatchlings significantly $(\mathrm{P}<0.05)$ increased continuously until $120^{\text {th }}$ day where maximum hatchlings were recorded (Table 1). STL $_{50}$ produced significantly more hatchlings than other substrates content across the experiment. Though in the second experiment the number of hatchlings produced by STL $_{50}$ was not significantly different from those produced in $\mathrm{STL}_{25}$ and $\mathrm{STL}_{75}$. An increase of hatchlings with the increase of days might be due to high presence of mature worms which were able to produce more cocoons (data on cocoons not shown) that contributed to more number of hatchlings. Sadia et al., (2020) reported the highest number of hatchlings where cocoons were numerous. Maximum number of hatchlings at STL $_{50}$ during this experiment gets supported by the findings of 
Bhat et al., (2015) as they reported maximum number of hatchlings of earthworms when cowdung was mixed with bagasse at equal ratio $(50 \%)$.

In conclusion based on the increments of worms with an increase of days of the experiment and the number of hatchlings produced, it can be concluded that Kigelia africana leaves as a waste can be an appropriate substrate for earthworms (Eisenia fetida). Maximum number of worms was observed at $105^{\text {th }}$ day. Weight of worms significantly decreased with the increase content of leaves. When the leaves were mixed with cowdung at an equal ratio $\left(\mathrm{STL}_{50}\right)$, higher number of hatchlings was attained. A follow up study is needed to evaluate the quantity and quality of vermicompost that can be produced from $K$. africana leaves.

\section{Acknowledgements}

I am thankful to the Ministry of Agricultural Development and Food Security, Botswana, for providing necessary facilities. My gratitude also to Mr M.R. Matsapa and Mr I. Mooketsi for mobilization of study materials and data collection under the supervision of Ms D. Kaisara.

\section{References}

Agyare, C., Dwobeng, A.S., Agyepong, N., Boakye, Y.D., Mensah, K.B., Ayande, P.G. and Adarkwa-Yiadom, M. 2013. Antimicrobial, antioxidant, and wound healing properties of Kigelia africana (Lam.) Beneth. and Strophathus hispidus DC. Advances in Pharmacological Sciences, $1-10$. http://dx.doi.org/10.1155/2013/692613.

Arkhipov, A., Sirdaarta, J., Matthews, B. and Cock, I.E. 2014. Metabolomic profiling of Kigelia africana extracts with anti- cancer activity by high resolution tandem mass spectroscopy. Pharmacognosy Communications, 4(4), $10-32$.

Bhat, S.A., Singh, J. and Vig, A.P. 2015. Potential utilization of bagasse as feed material for earthworm Eisenia fetida and production of vermicompost. SpringerPlus, $\quad 4(11), 1 \quad-\quad 9$. http://creativecommons.org/licenses/by/ 4.0

Bhat, S.A., Singh, J. and Vig, A.P. 2016.Effect on growth of earthworm and chemical parameters during vermicomposting of pressmud sludge mixed with cattle dung mixture. Procedia Environmental Science, 35, $425-434$

Devi, J. and Prakash, M. 2015. Microbial population dynamics during vermicomposting of three different substrates amended with cowdung. International Journal of Current Microbiology and Applied Sciences, 4(2), 1086 - 1092.

Dhungana, B.R., Jyothi, Y. and Das, K. 2016. Kigelia pinnata: Exploration of potential medicinal usage inhuman ailments.Journal of Pharmaceutical Research, 15(4), 138 - 146.

Hoklis, C. and Sharp, A. 2014. Greenhouse gas emission from municipal solid waste in Phnom Penh, Cambodia.GMSARN International Journal, 8(3),73 - 78 .

Hussaini, A. 2013. Vermiculture biotechnology: An effective tool for economic and environmental sustainability. African Journal of Environmental Science and Technology, $7(2), 56-60$

Karmegam, N. and Daniel, T. 2009. Growth, reproductive biology and life cycle of the vermicomposting earthworm, Perionyx ceylanensis Mich. (Oligochaeta: Megascolecidae). Bioresource Technology,100,4790 - 
4796.

Kibatu, T. and Mamo, M. 2014. Vermicompost and vermiwash on growth, yield and yield components of Beetroot (Beta vulgaris L.). World Applied Sciences Journal, 32(2),177 182.

Ndegwa, P.M., Thompson, S.A. and Das, K.C. 2000. Effects of stocking density and feeding rate on vermicomposting of biosolids. Bioresource Technology, 71,5 -12 .

Sadia, M.A., Hossain, M.A., Islam, M.R., Akter, T. and Shaha, D.C. 2020. Growth and reproduction performances of earthworm (Perionyx excavatus) fed with different organic waste materials. Journal of Advanced Veterinary and Animal Research, 7(2),331 - 337.

Sangwan, P., Kaushik, C.P. and Garg, V.K. 2010. Vermicomposting of sugar industry waste (press mud) mixed with cowdung employing an epigeic earthworm Eisenia fetida. Waste Management and Research, 28,71 - 75.

Siddique, J., Khan, A.A., Hussain, I. and Akhter, S. 2005. Growth and reproduction of earthworm (Eisenia fetida) in different organic media. Pakistan Journal of Zoology, 37(3),211 $-214$.
Sivertsen, B. 2006. Air pollution impacts from open air burning. Waste Management and the Environment III. WTI Transaction on Ecology and the Environment, 92,449-457.

Sogbesan, O.A. and Ugwumba, A.A.A. 2006. Effect of different substrates on growth and productivity of Nigeria Semi-Arid zone earthworm (Hyperiodrilus euryaulos, Clausen 1842) (Oligochaeta: Eudrilinae). World Journal of Zoology, 1(2), $103-112$.

Suthar, S. 2007. Influence of different food sources on growth and reproduction performance of composting Epigeics: Eudrilus eugeniae, Perionyx excavatus and Perionyx sansibaricus.Applied Ecology and Environmental Research, 5(2),79-92.

Tripathi, K.M., Dhakal, D.D., Baral, D.R. and Sharma, M.D. 2015. Effect of feeding materials on yield and quality of vermicompost and multiplication of Eisenia fetida in sub-tropical environment of Nepal. International Journal of Research, 2(7), 23 - 28.

Viljoen, S.A. and Reinecke, A.J. 1989. Lifecycle of the African nightcrawler, Eudrilus eugeniae (Oligochaeta).South African Journal of Zoology, 24(1),27 32.

\section{How to cite this article:}

Gagopale Bosekeng. 2021. Effects of Kigelia africana Leaves on Survival, Reproduction and Growth of Earthworm (Eisenia fetida). Int.J.Curr.Microbiol.App.Sci. 10(01): 3455-3460. doi: https://doi.org/10.20546/ijcmas.2021.1001.407 